\title{
E-Portfolios and Practicum in Teacher Education
}

\author{
Christine Ho Younghusband \\ School of Education \\ University of Northern British Columbia
}

\section{Correspondence:}

Christine Ho Younghusband

School of Education

University of Northern British Columbia

Email: christine.hoyounghusband [at] unbc.ca

\begin{abstract}
The Teacher Education Program at the University of Northern British Columbia (UNBC) implemented three initiatives in 2018 to improve the practicum experience for teacher candidates. One of these initiatives was to extend the use of e-Portfolios into final practicum. E-Portfolios are first developed by teacher candidates in EDUC 431, the Education Technology course, but they were asked to continue its use in the following term during final practicum. The extended use of e-Portfolios served as one response in the teacher education program to BC's Curriculum (2021) and changes in the K-12 system, which in turn modelled several aspects of BC's Curriculum such as personalization, Core Competencies, formative assessment, and the First Peoples Principles of Learning. Including final practicum as part of the e-Portfolio, teacher candidates were able to deepen their understanding of the Professional Standards for BC Educators (2019), reflect on their teaching experience, and conclude the program with a presentation at the Celebration of Learning. Teacher candidates were able to maintain an ePortfolio during final practicum, identify additional artefacts to demonstrate their understanding of the professional standards, and create a digital narrative describing who they are as educators.
\end{abstract}

Keywords: e-portfolio, practicum, teacher education, professional identity 


\section{Introduction}

The University of Northern British Columbia (UNBC) is a small research university that offers a 2-year post-baccalaureate Teacher Education Program (TEP) for secondary and elementary cohorts. In 2018, the TEP pursued several initiatives to improve the practicum experience for teacher candidates (TCs) and to align the program to BC's Curriculum (2021). Three initiatives introduced into final practicum were triads, single point rubrics, and e-Portfolios. All three initiatives are interrelated, focused on the Professional Standards for BC Educators (2019), and student led. This paper focuses on the implementation of e-Portfolios during final practicum. What was learned from this initiative would inform future programming.

\section{System Change}

British Columbia (BC) K-12 education system introduced a new curriculum in 2016 for all grade levels in all subject areas, which was fully implemented by 2019. BC's Curriculum (2021) is concept-based, competency-driven learning focused on personalization and The Educated Citizen (1989). The curriculum is student-centred, provides flexibility and choice, and continues to emphasize numeracy and literacy foundations. Indigenous or First Peoples content and curricular competencies are embedded in all subject areas and grade levels in addition to the First Peoples Principles of Learning (2008). The Big Ideas and Core Competencies lend themselves to interdisciplinary learning experiences and learning beyond the classroom. Inquiry based learning, flexible learning spaces, and formative assessment are encouraged.

The changes introduced in BC's Curriculum were in response to the technology-rich world in which students live in where information is constantly changing and easily accessible (BC Ministry of Education, 2021). Content was no longer the central focus of BC's Curriculum, but competencies. As a result, teacher education programs (TEPs) must also transform to prepare TCs on how to use the new curriculum, but also teach in this new environment. In this TEP, one step towards change was to extend the use of e-Portfolios into final practicum. TCs create an ePortfolio in EDUC 431 (Education Technology) in Term 3 (of 4) and final practicum (EDUC 491) occurs in Term 4. The initiative was to continue its use.

TCs would independently identity additional artefacts during their 10-week practicum that best reflected their teaching philosophy, the professional standards (Kitchenham, 2008; Paul \& Scholefeld, 2009), and who they were as teachers (Palmer, 1989). TCs would critically reflect on their teaching experience, make connections between new knowledge and prior knowledge, and self-monitor and self-assess how they are doing (Earl, 2003) with respect to the standards. They would further develop their EdTech skills in addition to digital citizenship and literacy. The TEP would conclude with a Celebration of Learning where TCs referred to their digital narrative and presented what they have learned to first year TCs, faculty, and school district staff.

\section{Connections to Curriculum}

Extending the use of e-Portfolios into final practicum allowed TCs to experience part of BC's Curriculum and demonstrate several professional standards. The use of e-Portfolios was student centered and competency based. They provided TCs choice and flexibility to web design, artefacts selected, and web applications (i.e., videos, vlogging, photos, and social media). TCs tracked their learning over time to identify areas of strength and areas for growth. Although TCs were encouraged to include exemplars from other coursework and previous practicum experiences, some TCs included content that from past experiences (i.e., 
certifications, second language, or employment) or personal interests (i.e., cooking, coaching, or family life) to highlight competencies or skill sets that were not part of their formal education, but possibly beneficial to the teaching profession. E-Portfolios were subjected to ongoing formative assessment by peers, self, or instructor based on a shared set of criteria and expectations.

TCs developed ownership of their e-Portfolios. They had agency and autonomy to design, develop, and create content to choreograph a digital narrative of their professional identity. Engaging in e-Portfolios modelled aspects of the First Peoples Principles of Learning (2008). TCs explored their identity; created a website that was experiential, reflective, and holistic; developed their teaching expertise which required patience and time; made connections to self, the land, and community; understood that there were consequences to one's actions; recognized their role and responsibilities as teacher; and embedded their learning into (a digital) story. Not only were TCs learning experientially about digital literacy, digital citizenship, and their digital footprint from continuing their use of e-Portfolios during final practicum, but they were also demonstrating Standard 2 (professionalism), Standard 7 (professional learning), and Standard 8 (contribution to the profession) of the Professional Standards for BC Educators (BC Teachers' Council, 2019); and experienced some of the intentions of BC's Curriculum in terms of the Core Competencies, formative assessment, and First Peoples Principles of Learning.

\section{Experiential Learning}

Implementing the extended use of e-Portfolios into final practicum was a meta-learning experience for the course instructor as TCs created e-Portfolios as part of the Teacher Education Program (TEP). Based on Kolb's (1984) experiential learning cycle, one would start with an experience, reflect on that experience, reconceptualize the experience, and try again. This framework for learning was one that TCs enacted to create the various pages for their ePortfolios over time and one that I took as faculty member who taught the final practicum course and initiated the extended use of e-Portfolios. I was learning experientially while TCs developed their e-Portfolios experientially. I am not an EdTech expert, but I use Twitter for professional learning and learning network and maintain a WordPress website and blog.

Reflection is an integral part of experiential learning and developing a reflective practice. According to Schön's (1984) reflective practitioner, teachers "reflect in" and "reflect on" practice. They reflect while the teach and make decisions in real time, but also, they can reflect on what was experienced and consider what could be done differently for next time. This act of selfmonitoring and self-assessment is called Assessment as Learning where one thinks about their thinking to further their understandings (Earl, 2003). As the course instructor, I learned from the EDUC 431 instructors, worked with the Centre for Teaching, Learning, and Technology (CTLT) at the university to create a WordPress template using OpenETC - Free Range EdTech (which was FIPPA compliant), and collaborated with other practicum instructors. TCs worked with their peers from their triad or cohort, connected with the course instructor, and had clear criteria for self-assessment to develop an e-Portfolio independently and autonomously during practicum.

\section{Concluding Remarks}

"Good teaching cannot be reduced to technique; good teaching comes from the identity and integrity of the teacher" (Palmer, 1989, p. 10). E-Portfolios during final practicum provided TCs with a digital platform to explore their identities as learner and educator, make connections between theory and practice, and find artefacts that best reflected the professional standards and who they are as a digital narrative. It was a vehicle for creation, reflection, and celebration.

Open/Technology in Education, Society, and Scholarship Association Conference Proceedings: 2021, Vol. 1(1) 1-5 
The program concluded with the Celebration of Learning and a summative presentation and TCs were able to maintain their e-Portfolios during practicum. E-Portfolios were personalized and extending its use into final practicum enabled many elements of BC's Curriculum into the program. As faculty, I learned alongside with the TCs during this initiative, and they taught me what was possible. The e-Portfolio was a humanizing experience where TCs developed a sense of agency and started to recognize their professional identity.

\section{Author's Contributions}

The author confirms sole responsibility for the following: study conception and design, data collection, analysis and interpretation of results, and manuscript preparation.

\section{Open Researcher and Contributor Identifier (ORCID)}

Christine Ho Younghusband (iD https://orcid.org/0000-0002-0804-3537

\section{Acknowledgements}

The Open Educational Technology Collective (OpenETC) is acknowledged for their contributions in supporting the innovative portfolio system used in this design.

\section{Ethics Statement}

Ethics review was not applicable because the inquiry was about evaluating and improving the program.

\section{Conflict of Interest}

The author does not declare any conflict of interest.

\section{Data Availability Statement}

Data sharing is not applicable to this article as no new data were created or analyzed in this study.

\section{References}

BC Ministry of Education. (1989). Statement of education policy order (Mandate for the school system). https://www2.gov.bc.ca/assets/gov/education/administration/legislationpolicy/legislation/schoollaw/d/oic 128089.pdf

BC Ministry of Education. (2021). BC's Curriculum. https://curriculum.gov.bc.ca/

BC Teachers' Council. (2019). Professional standards for BC educators. https://www2.gov.bc.ca/assets/gov/education/kindergarten-to-grade-12/teach/teacherregulation/standards-for-educators/edu standards.pdf

Earl, L. M. (2003). Assessment as learning using classroom assessment to maximize student learning. Corwin Press.

First Nations Education Steering Committee. (2008). First Peoples principles of learning. http://www.fnesc.ca/wp/wp-content/uploads/2015/09/PUB-LFP-POSTER-Principles-ofLearning-First-Peoples-poster-11x17.pdf

Kitchenham, A. (2008). E-portfolios in teacher education: The UNBC experience. Collected Essays on Learning and Teaching, 1(2008), 142-148. https://doi.org/10.22329/celt.v1i0.3194 
Kolb, D. (1984). Experiential learning: Experience as the source of learning and development. Prentice Hall.

https://pdfs.semanticscholar.org/f6ec/20a7a3150822140be7466353d0de572cc4bb.pdf

Palmer, P. (1989). The courage to teach: Exploring the inner landscape of a teacher's life. Jossey-Bass.

Paul, C., \& Scholefeld, A. (2009, September 22). E-Portfolios for teacher candidates. The Centre for Teaching, Learning and Technology: University of British Columbia. https://ctlt.ubc.ca/2009/09/22/e-portfolios-for-teacher-candidates/

Schon, D. A. (1984). The reflective practitioner: How professionals think in action. Basic Books. 